PITLE

Rapld Sequencing of DNA Baged on Single Molecule Detection

AUTMOASI

Steven A. Soper, Lloyd M. Davis, Frederie R. Fairfield. Mark L. Hamond, Carol A. Harger, James H. Jete, Richard A. Keller, Babbetta L. Marrone, John C.Marrin, Harvey I. . Nutter, E.Brooks Shera and Daniel J. Simpson

SUBMIT TED TO

\section{SPIE Proceedings}

\section{DISCLAIMER}

This repon we prepared as un ecowunt of wort spunaured by an agency of the Uniled State Government. Neither the United Sintes (iuvernment lior any agency thereof, nor any of thair

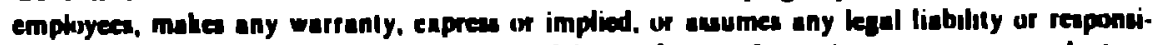
bility for the eccurecy, campletenew, or unefulnea of any ir.formation, apparatun, product, or proves disclosod. or represents that us use would not infringe privately owned rights Kofer.

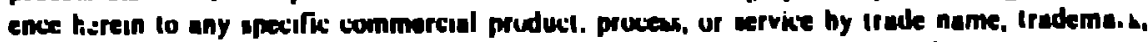

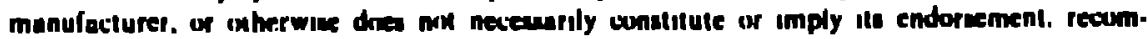

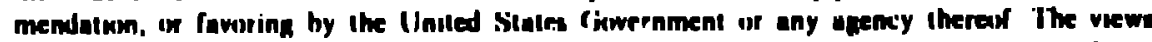

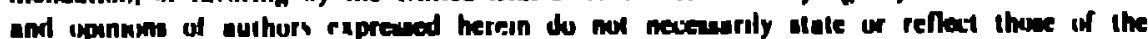
Initad Situtes Givernnient of any arency thereor.
LA-UR--91-562

DB91 008591 
Rapid Sequencing of DNA Based On Single Molecule Detection

Stevon A. Soper, Lloyd. M. Davis, Frederfc R. Falrfleld, Mark L. Hammond, Carol A. Harger, Jamos H. Jett, Richard A. Keller, Babbetta L. Marrone. John C. Martin, Harvey L. Nutter. E. Brooks Shera, Daniel J. Simpson

Center for Human Genome Studies
Los Alamos Natlonal Laboratory
Los Alamos, NM 87545

\section{ABSTRACT}

Soyuencing the human genome is a major undertaking considering the large number of nuclootides present in the genome and the slow methods currently avallable to perform the task. Wo have recently reported on a scheme to sequencu DNA rapidly using a non-gal based technlque. The concept is based upon the Incorporation of fluorascently labeled nucleotides Into a serand of DNA, isolation and manipulation of a labeled DNA frazment and the detection of single nuclestides using ultra-sensicive laser-Induced fluorescence detection following their cleavage from the fragment. Detection of Individual fluorophores in the I Lquid phase vas accomplished with time-gated detection following pulsed-laser excltacion. The phocon bursts from individual rhodamine 6G (R6G) moleculeg travelling through a laser beam have been observed as have bursts from single fluorescently modifled nucleotldes. Using two different blotinylated nucleotides as a model system for fluorescently labeled nucleotides, we have ubserved synchesis of the complementary copy of Mlz bacterlophage. Work with fluoliescently labeled nucleotides is inderway. We have observed and manipulated Indlyidual molecules of DNA attached to a inlcrobead with an eplfluorescence microscope.

\section{INTRODUCTION}

Presently, there is a major effort to map and sequance the human genome. This Ls a formidable task because the human genime contalns 3 × $10^{\circ}$ nucleotides. Currently used technlques can sequence a few hundred to a few thousands bases per day. The cominon equencing pro:ocols are those developed by Sanger (1) or Maxam and vilbert (2) atid are gol based tochniques using elther cadinactivelv or fluorescently labeled nur.leotides. Current methods requlte the use of oi.: (1) Cour lanas of the gel and a vast number of Ident lcal DNA molecules whlch yleld a fow hundred bases of sequence $(3,4)$, Longer DNA sequences are corgtricted hv nverlapplng the short sequences If the DNA sequent: of tritereit is a million bases long. current metliodologles of ovel bipplng shore sequences beromes prohlblelva, While gel based sequencligg rechnlques are Improvlug, bases

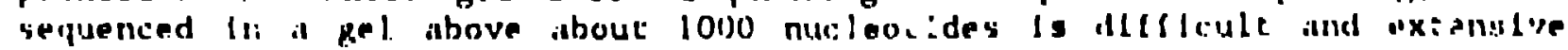


manposer and time are requited for these gel cechniques.

Recently, we have reporced on a new method of sequencing DNA it a rate approaching several hundred bases per second $(5,6)$. The cechnique Involves: (a) labeling the nucleotides with base specific tags sultable for ultra-sensitive fluorescence detection, (b) enzymatic synthesis of a complementary strand of DNA usirig fluorescently-labeled nucleotides, (c) isolation and manipulation of a single molecule of fluoregcently latiled DNA, (d) suspension of the single DNA molecule in a flowing sample stream, (e) sequential cleavage of fluorescently labeled nucleotides from the DNA and (f) detection of single fluorescently labeled nucleotides as they pass through a focused laser beam. The sequencing rate of this method should be $11 \mathrm{mited}$ by the rate at which the exonuclease can remove single DNA bases from the terminus of the DNA molecule and the rate of detection of single molecules. Our method should be able to determine the sequence of very long pleces of DNA (e.g. The $40 \mathrm{~Kb}$ DNA fragments In a cosmid library) directiy without the need for overlapping short DNA sequences.

Tile success of this proposed method depends upon the ability to detect individual fluorescent molecules in solucion as they transic a focused laser beam. Work in the area of single molecule detection (SMD) was Initlated by Hirschfeld who labeled one molecule (polyethyleneimine) with fluorescein Isothlocyanate molecules and was able to detect 80 fluorophores in a static system (7). Dovichl ant coworkers utllized rhodamine 6G (R6G) as the fluorophore and hydrodynamic focused flows and were able to see a few thousand molecules $(8,9)$. Thls work was followed by a report of songitive fluorescence detection from molecules of phycoerythrin, equivalent to 25.30 R6G molecules based upon differences in the molar absorptivities and iluorescent quantum efficlancles (10). Peck et al. later demonstraced Indirect prouf of detection of single molecules of phycoerythrin in solution (11). The work wich phycoerythrin was followed by improvements in sensitivity. approaching the single molecule level for the fluorophore R6G using CW excltation (12.13). We have recently reported on the flrst direct observacion of the photon burst trom Indivitual R6G molecules traveliling through a focused laser beam using pulsed. laser excltation and time-gated detection (14). The use of time-gated detection effectively discriminates the scattering background from the fluorescence and resules in a substantlal decrease in the observed background. Our recent progress in the rrea of single molecule lacection will be discussed as well as our progress in the area of DNA replication ising labeled nucleotides and the lsolation and manlpulation of Individual molecules of DNA.

\section{EXPERLMENTAL}

The pulsed-laser SMD apparatug has been descrlted elsewhere (14). Brietly, the excltation gource was an actively mode-locked Nd:YAC laser with a repetielon race of $\mathrm{H} 2 \mathrm{MHz}$ and pulse widch of $70 \mathrm{peec}$. The fundamental was frequency-doubled - o 532 un with average powers of $30 \mathrm{~mW}$ at the flow cell. S'nce the tiuorescent litetime and $t$ ! Lnvelse of the laser repetltlon rate are much shorter than the Ime rhe molecule sperds In the laser beam. The molmoule Is re-exclted many times iesuleing, Ing burst of photons that serves ay a signature for the passage ot 
nolecules through the laser beam. A microscope objective and a slit are arranged to image the photons from a small region acound the laser beam walst onto a microchannel plate photomultiplier (MCP) operated in the single-photon counting mode (see Figure 1).

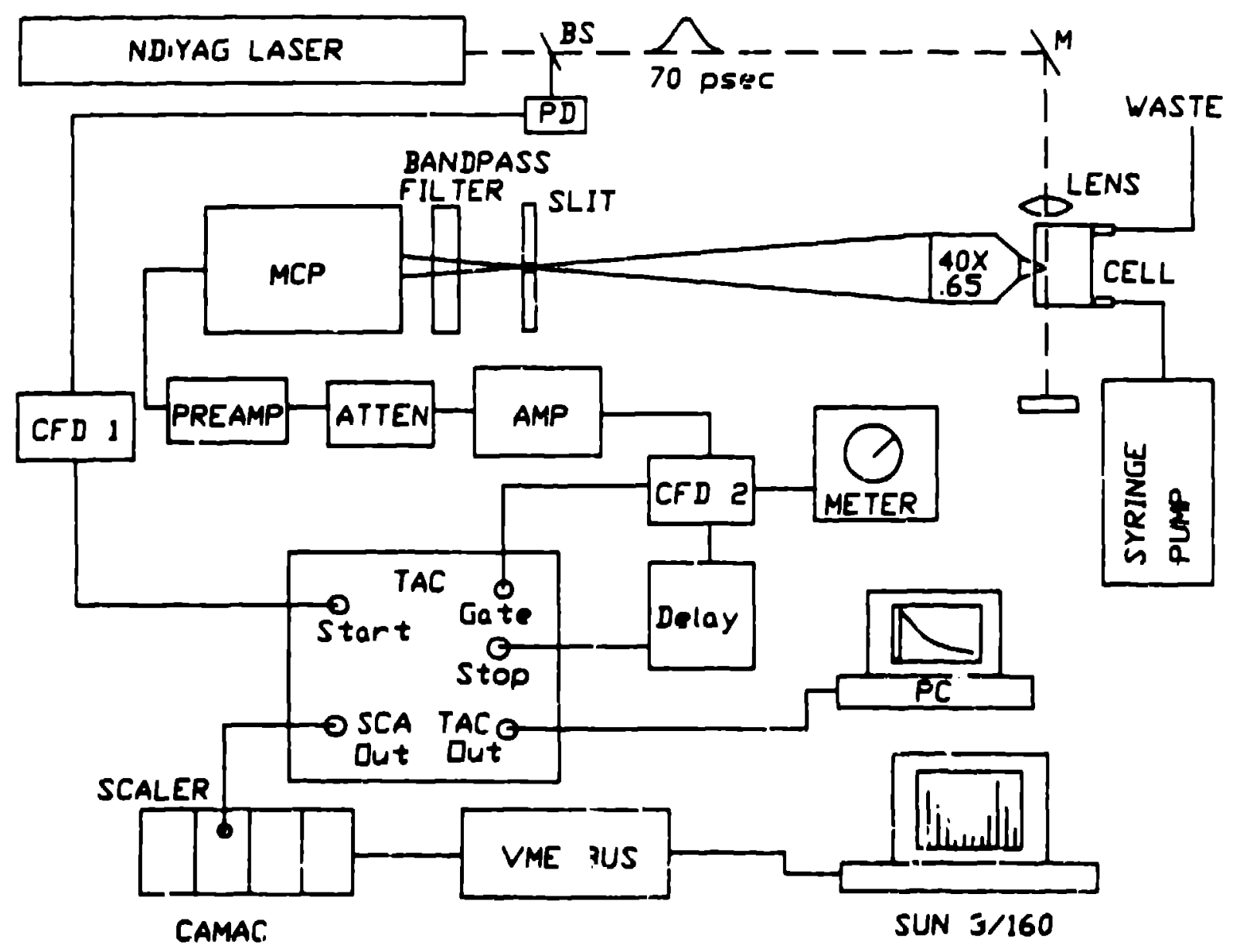

Flgure 1. Schematic draving of the SMD apparatus. The pulsed light was focusced onto the loxa mm llow cell with a $17 \mathrm{~mm}$ socal length lens ylelding a measured beam waist of $7.5 \mathrm{um}(\mathrm{l} / \mathrm{a})$. Part of the esiltation beam was dlrected to a pholodlode to provide the start pulse for the lac. The stop pulse was generated from the anode pulses of the MCP PMT. The fluorescence emission was collpctad by a :0X. NA $0.65 \mathrm{mlcroscope}$ objectlye and linaged unto a vat lcal s!lt wlth a wilth set at 1).4 mm tesulting in a 10 un obscrvation distance along the propigation axls of the laser beam. Scatterlng linplnglng onto tie Mcp rMT was

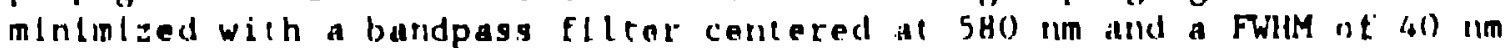


Photostabilities of varlous fluorophores were measured using the $C W$ excitation from an Ar ion laser (514.5 nm). The remainder of the CW apparatus has been descrtbed in detall elsewhere (13). The photobleaching efficiencles were measured according to the procedure described by Mathies and Stryer (15). The method Involves measuring the normalized fliorescence intensity as a function of the flow velocicy, ylelding a sigmoldally shaped curve from which the photobleaching efflciency can be obcalned.

The DNA fragments were observed under a conventional epifluorescence microscope (Lelcz Laborlux) equipped with a cooled Photometrics CCD camera detector for sensitive fluorescence detection. The DNAs were siained with ethidium bromide in order to observe the fluorescence of the DNA molecules.

\section{SINGLE MOLECULE DETECTION OF LABELED NUCLEOTIDES}

A number of different photophysical parameters play important roles in determining the ability to detect selected fluorophores on a single molecule level. The pinotobleaching efflciency sets an upper limlt on the number of photons one can obtain per molecule and therefore plays a cructal role in determining the durition of the photon burst for the molecule under observation. Table 1 presents the fluorescence quantum efflclencv $\left(\Phi_{l}\right)$, photobleaching efficlency $\left(\Phi_{d}\right)$ and the tocal number of photons atcalnable per molecule ( $\left.\Phi_{f} / \Phi_{f}\right)$ for R6G, tetramethylrhudamine lsothiocyanate (TRITC) and adenine labeled wi:h TRITC (TRITC-AD). TRITC and TRITC-AD are typlcal fluorophores that will be used In the rapid sequencing scheme. In the case of R6G, approximately 25000 photons per molecule can be obtalned in an aqueous solvent. Fur 0.001 photoelectrons

Table 1. The fluorescence quantum offlclency $\left(\phi_{l}\right)$, photobleaching efflclency $\left(\Phi_{1}\right)$ and photon yleld per molecule (N) for RGG. TRITC and TRITC.AD In $H_{2} O$ and $\mathrm{ECOH}$.

\begin{tabular}{|c|c|c|c|c|c|c|c|c|c|}
\hline \multicolumn{2}{|c|}{ Solvent } & $R 60$ & \multicolumn{5}{|c|}{ TRITC } & \multicolumn{2}{|c|}{$\because R N T C-A D$} \\
\hline & $\Phi$ & B. 1 & $N$ & $\Phi_{2}$ & $\Phi_{1}$ & $N$ & $\Phi$ & $\Phi_{1}$ & $N$ \\
\hline$H_{2}(1)$ & $0 . .+5$ & $1.8 \times 10^{-9}$ & $2.5 \times 10^{6}$ & $0.1 \%$ & $5.11 \times 10^{3}$ & $3.0 \times 10^{6}$ & 1). 14 & b. $4 \times 10^{3}$ & $2.2 \times 10^{4}$ \\
\hline EtoH & (1). 48 & $5.0 \times 10 \%$ & 1. $f \times x 10^{\circ}$ & 0.26 & is. $2 \times 10^{-1}$ & 6. $2 \times 11^{9}$ & $0.2 \%$ & 6. $4 \times 10^{-1}$ & $3.4 \times 10^{3}$ \\
\hline
\end{tabular}


per photon generated (taking into account quantur efficiency of phototube, geometric collection efficlency and transmission efflciency of the fllters), then approximately 25 photoelectrons are detected per molecule. In EtOH, the photon vield per molecule is $1.6 \times 10^{\circ}$ due to an 100 fold improvement in its photostabliity. We have been able to utllize the increased photon yleld of R6G in EtOH to observe the bursts of photons from individual molecules of R6C using $C W$ excltation as indicated from non-random correlations in the autocorrelation function and tails in the Fulsson distributions (13). For TRITC and TRITC-AD, the fluorescence quantum $Y$ ields are approximately $3 x$ smaller than that of $R 6 C$ in $\mathrm{H}_{2} \mathrm{O}$. But due to thelr Increased ptotostability, these fluorophores result in nearly the same number of photons per molecule as that seen for R6G.

We are able to decect individual molecules of R6G transiting a focused lacer beam using pulsed-laser exclcacion and time-gaced detection (14). Sing'e molecule detection was based on (a) the observation of a non-random correlation In the autocortelation function and (b) the direct observacion of the burst of photons from single R6C molecules in solution. The autocorrelacton function, $G(r)$. for discretely sampled data can be expressed as

$$
G(r)-\sum_{t=0}^{N-1} d(\tau) d(t+r),
$$

where $N$ Is the number of data points analyzed and $i$ is the delay, As can be seen from equation ( 1 ), the autocorrelation 1 s performed on the entire data set and Is thus compuced over a large number of events. The non-random cortelarion is evidence for observing the bursts from a number of molecules passing, through the laser beam during the course of the experiment and persist for delays up to the iverage residence $t$ lme of the molecule within the laser beam. With the knowledge of the phutobleaching race, the flow velocl:y and the dlameter of the laser beam. one can calculate the effective residence cime of a moleculo within the laser beam. In the case of TRITC or TRITC.AD In $h_{2} O$ and leser powers of $30 \mathrm{~mW}$ the average effect Ive lifet Ime of the fluorophore (before vleaching) is approximatelv $15 \mathrm{msec}$ whereas the transit time (laser beam dlal.ter / flow velocitv) Is approximately $30 \mathrm{msec}$. Theiefore, a majority of the molecules are photobleached befor. exiting the laser beam. The autocorrelation tunction for $100 \mathrm{EM}$ of TRITC-AD and Eor the water solvent are shown In Flgure 2. A strong non-random autocotrelation was seen oily in the case of TRITC.AD. ThIs conientration of IRITC-AD was ihosen to yield a probabllity of a single molecule residing within the laser beim at ally glven time of 0.1 thereby minlmLing the probablilty of two nolociles restding within the iaser beam

The iutcortelation is computad over a lalige number of events and does not. Iden.. Ify cile passage of Indlvidual molecules is they transte the laser beam, an essential repulrement $i n$ the rapid sequencing methodology since each molecule 
must be processed individually. In order to examine th. data for passage of individual molecules, we have defined a welghted quadratic summing (WQS) fiiter given by (ref. 14)

$$
S(t)-\sum_{r=0}^{k-1} w(r) d(t+r)^{2}
$$

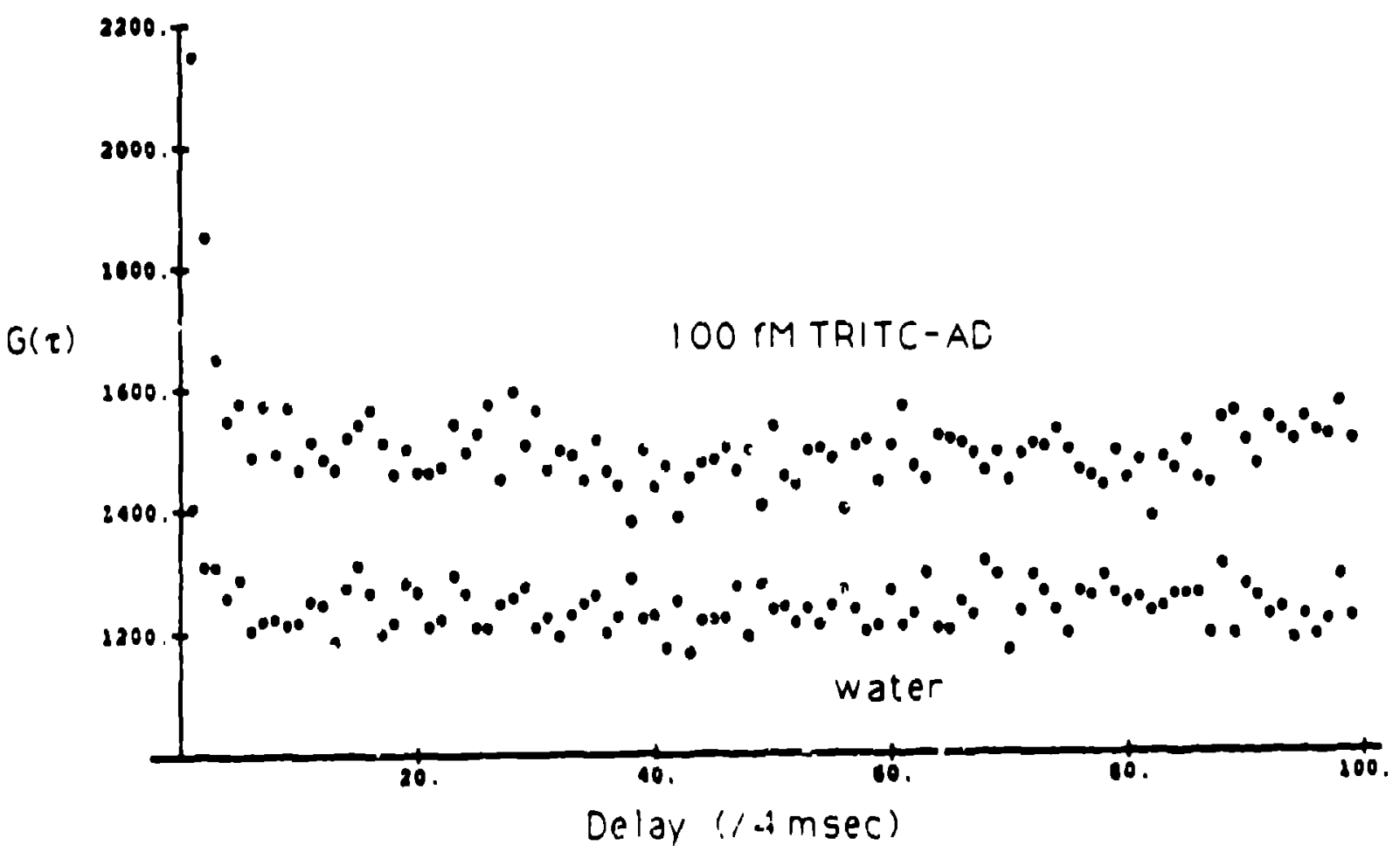

Figure? Autocorrelation plots for water and water wlth the addition of lon tri of TRITCi-AD. The average Laser power was $30 \mathrm{~mW}$ and the autocortelation was computed over laz sec of dala collectiou. 
where $k$ covers the time interval on the order of the molecular passage time (In the present experiment $k$ - 5, corresponding to 20 msec, 4 msec per councing incerval) and $w(r)$ are weighting factors chosen to best discriminace the signal due co passing molecules from random fluctuations in the background. The values of these weights were based on resulis from computer simulations of the expected slgnal from passage of individual molecules through the laser beam. In the present case $w(r)$ - $(r+1) / k$, for $r$ - 0 to $k$ - I (an asymmetric triangular ramp due to the fact that the signal increases slowly as the molecule enters the laser beam followed by an abrupt cessation of photon emission due to photobleaching). Figure 3 shows the WQS filcered data for the blank and $100 \mathrm{FM}$ of TRITC-AD. Small amplitude bursts are observed in the blank due to statistical fluctuations of the background and to fluorescent Impurities. Upon addiclon of TRITC-AD, large amplitude bursts are observed in the data. The average number of photoelectrons observed per burst is roughly 10 , In accordance with the data of Table 1 (22000 photons per molecule) and the conversion efficiency of the pulsed-laser SMD apparatus ( 0.0007 photoelectrons / photon). Based upon the estimated flow velocity, the concericration of the fluorophore used in this experiment and the size of the observation voiume (1.8 pL), the calculated number of molecules passing through the laser beam is approximately 1 per sec. If onn sets a discriminator ac $S(t)$ - 10 , then the assoclated detection efficlency for single molecules of TPITC-AD transiting the laser beam is nearly 70 with an error rate (due to fluorescence impurities present in the solvent blank and staristical fluctuations in the background) of approximately 0.03 per sec.

Our ability to detect individual molecules of the nucleotide adentne labeles with IRITC is signiflcant not only in terms of our rapid DNA sequencing scheme, but for applying SMD to varlous types of analytical applications where fluorophores are actached to analytes. TRITC-AD shows a reduced quantum yleld for fluorescence as compared to $R 6 C$ (see Table 1), but, because of its increased photostability, results in similar photon yields per molecule. The results from reference 14 for $R 6 G$ and that from Flgure 3 indicate that selection of molecules for SMD should not be based solely on the fluoresrence quantum ylelds, but should Include considerations based upon photostablilicy as well.

\section{REPLICATION OF DNA WITH MOUIFIED NJCLEOTIDES}

In para:lel with single molecule detection. we are also making progress with the blochemlcal methods necessary to lab $\geq 1$ a fragment of DNA In preparacion for sequencing. DNA will be labeled bv racting a single-stranded template with modlfled nuclertides in the presence of a polymerase enzyme. This will create a labeled, double-stranded DNA fragment. The current method for single moleculo decection in the rapld DNA sequencing profect requires that tha nucleocides be labeled whth a fluorescent tag dup to the small quancum yields for fluorescence of the natlve nucleocldes. Actachment of an approprlace fluorescent dyo will be made via a linker arm to a postiton on the base. Bocause fluorescently tagged nucleotides were not ver commerclally avallable, Inlthal experiments utilized hiotin-modifled nucleutides to Invastlgate the e-ymatic synthesis of labeled DNA fragments and thelr subsequent cleavage by exonucleases. These experiments 

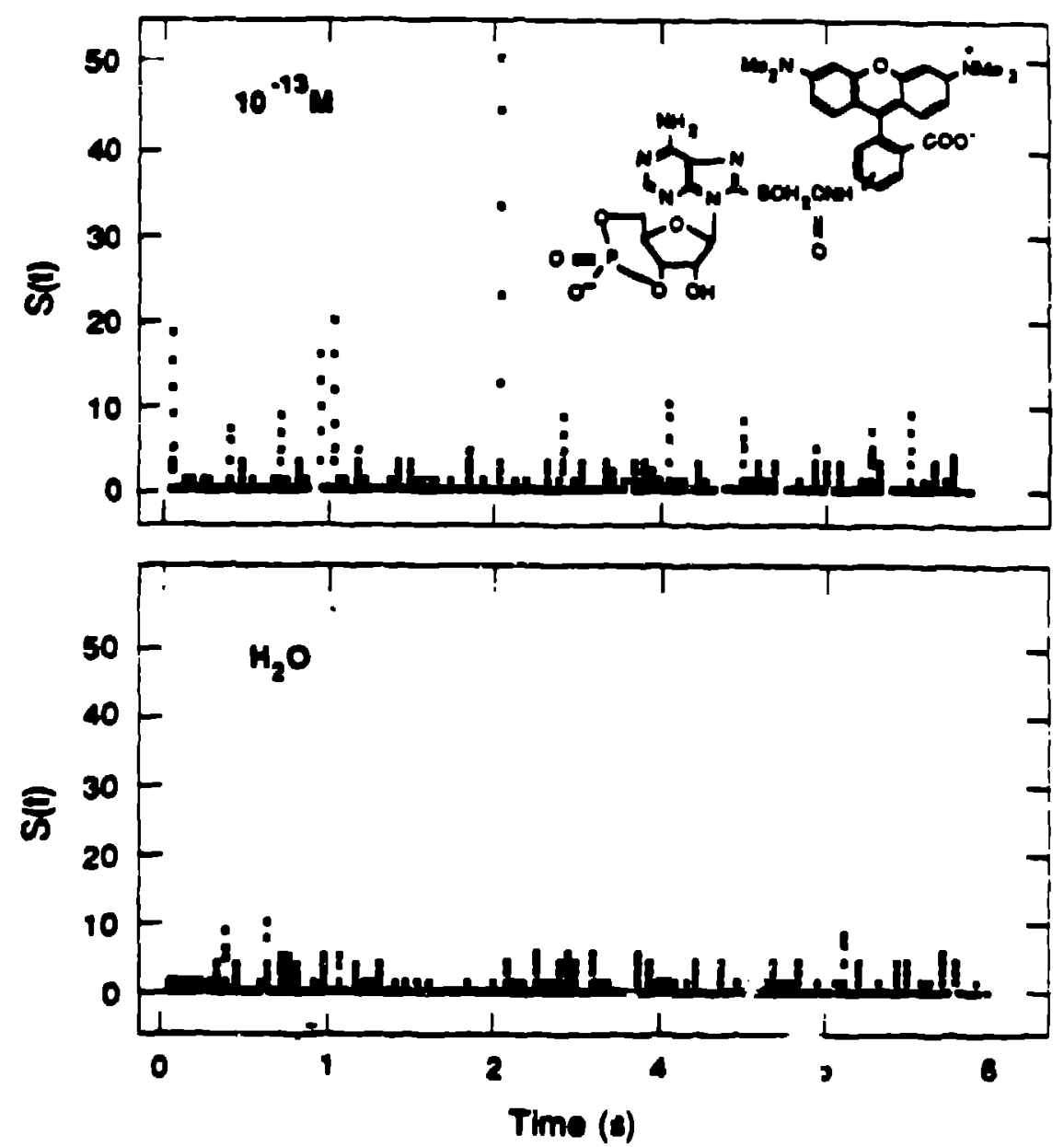

Figure 3. WQS fllter plot for 100 EM of TRITC-AD in water and wate $L^{-}$ith no added TRITC-AD. The structure of TRITC-AD is given in the upper right hand corner of the figure. At the concentration used in this oxperiment, approximately 1 molecule passes througil the detection volume per second. The conditions of this experiment were the same as those of Flgure 2 .

demonstrated Incorporation of bleiln-labeled nucleotides Into strands cumplementary to simple poly(dA, CG) DNA polymerg as well as the exonucleolytic digestion of this blotin.labeled duplex (3). We have also synthesized strands complementary to more complex 13 congtructs $w$ th two blot $1 n-1$ ibeled nucleotides, 
blotin-7-dATP and biotin-11-dUTP. Recently, flucrescently modified nucleotides have become avaflable. Preliminary experiments suggest that these nucleotides incorporate poorly under standard reaction conditions. In some cases the rate of incorporation of unmodifled nucleotides was inhibited by the fluorescent nucleotides. We anticipate that our current investigations into the mechanisms involved in this inhibition of DNA synthesis will allow us to determine appropriate linker arm structures and attachment positions so that we may design fluorescently tagged nucleotides that will incorporate rapidly and efficiently.

\section{ISOLATION AND MANIPULATION OF DNA}

Our technique requires the ability to select, attach and manipulate Individual DNA molecules. To this end, we have been exploring the attachment of Individual DNA molecules to supportive structures and the manipulation of these supported DNA molecules. As in the synthesis of modifled DNA, we are using a model system to simulate the final tagged DNAs. The model system consists of bacteriophage lambda double-stranded DNA to mimlc the size of our eventual tagged DNA $(40 \mathrm{~Kb}$ ) and ethidium bromide (a fluorescent dye that intercalates into DNA) to mimic the fluorescent tags. Using the cooled CCD camera coupled to a flusrescence microscope and appropriate filters to detect the fluorescence of ethidium stalned DNA, we are able to observe small fluorescent objects that have the proper moblilty, size and sensicivicy to DNase expected of individual lambda DNA molecules. Periorming these experiments was made feastble by the construction of a microscoplc gel electrophoresis apparatus. The apparatus allows one to observe the motion, fluorescence intensity and digestion of the DNA while within the field of view of the microscope in order to confirm that the object under observation is. In fact, an individual molecule of lambda DNA. While we belleve that we are isolating individual DNA molecules, thare is a potential problem becasse lambda DNA can form aggregates under our solution and dilution conditions. We are pursuing electronic. enzymatlc, and blological techniques to confirm that our smallest objects are Indeed single molecules and not aggregates of a few molecules.

To manipulaze Individual molocules of DNA, some type of solid support is necessary. Our original contention was to use avidin-coated inere microbeads of a few microns in dlameter (5). The avidin would bind blotin-modifled nucleotides that had been previously incorporated Into the modifled DNA. Since l!miting the number of attached DNAs to one by this method is rechnically difficult, we have attempted to support the DNA by fits known a'jllity to bind to glass microbeads. Even though this is also difficult, attaching apparenty single DNA molecules to glass beads has been successful.

To move these supported DNAs into the sequencer, a method is needed to both transport the microsphere lite the flow region and to hold it in place during the sequencing. We are currently evaluating optical traps (counter propagating focused laser beams that act as small tweezers (16)) and a number of different blological methods to make the manipulation process less tedious. Since supported DNAs must be digosted one nucleotide at a time, we are also 
investigating whether the presence of the support alters the enzymatic properties of the DNA exonucleases to create new products of the digestion or to make parts of the DNA unavailable for digestion.

\section{CONCLUSI INS}

The ability to sequence DNA based upon single molecule detection will have important ramifications in molecular biology. Although much work needs to be accomplished, significant progress has been made. We have successfully observed the individual photon bursts from nucleotides tagged with fluorogenic tags, completely replicated the bacteriophage M13 using two different biotiny ated nucleotides, attached a single molecule of lambda DNA to a solid support and observed the fluorescence of this single DNA molecule under an epifluorescence microscope. Research will. be focused on linker arm design to facilitate incorporation of fluorescently labeled nucleotides Into nascent DNA, to suspend a supported strand of DNA in a flowing sample stream and expanding our single molecule detection capabilities to observe fluosonhores of different colors in. a single experiment.

\section{ACKNOWLEDGMENTS}

This research was supported by a grant from the Department of Energy, Office of Health and Environmental Research.

\section{REFERENCES}

1. F. Sanger, S. Nicklen and A.R. Coulson, Proc. Natl, Acad, Sc1. USA, 74 , 5463. (1977).

2. A.M. Maxam and W. Gilbert, Meth. Enzym., 65,4499(1980).

3. L.M. Smith. J.Z. Sanders, R.J. Kaiser, P. Hushes, C. Dodd, C.R. Cornell, C. Heiner, S.B.H. Kent and L.E. Hood, Nature, 321, 674, (1985).

4. J.M. Prober, G.L. Trainor, R.J. Dam, F.W. Hobbs, C.W. Rot.artson, R.J. Zagursky, A.J. Cocuzza, M.A. Jensen and $K$. Baumelster. Science, $238,330$. (1987)

5. J.H. Jett, R.A. Kelier, J.C. Martin, B.L. Marone, R.K. Moyzts, R.L. Ratliff, N.K. Seitzinger E.B. Shera and C.C. Stewart, J. Biomol. Struc. and Dynamics, $7,301,(1989)$. 
6. L. M. Davis, F.R. Falrfield, C.A. Harger. J.H. Jete, R.A. Keller, J.H. Hahn, L.A. Krakowsk1, B.L. Marrone, J.C. Martin, H.L. Nutter, R. L. Ratliff, E.B. Shera, D.J. Simpson and S.A. Soper, Genetic Anal. (in press).

7. T. Hirschfeld, Appl. Opt., 15, 2965, (1976).

8. N.J. Lovichi, J.C. Martín, J.H. Jett, M. Trukula and R.A. Keller, Anal. Chem. , 56, 348, (1984).

9. N.J. Dovichi, J.C. Martin, J.H. Jett and R.A. Keller, Sclence, 219, 845, (1983).

10. D.C. Nguyen, R.A. Keller, J.H. Jett and J.C. Martin, Anal. Chem., 59, 2158, (1987).

11. K. Peck, L. Stryer, A.N. Glazer and R.A. Mathles, Proc. Nacl, Acad. Sci. USA. 86, 4087, (1989).

12 H.H. Hahn, S.A. Soper, J.H. Jett, J.C. Martin, H.L. Nutter and R.A. Keller, Appl. Spectrosc. (accepted for publication).

13. S.A. Soper, E.B. Shera, J.C. Martin, J.H. Jett, J.H. Hahn, H.L. Nutter and R.A. Keller, Anal. Chem. (accepted for publicarion).

14. E.B. Shera, N.K. Seltzinger, L.M. Divis, R.A. Keller and S.A. Soper, Chem. Phys. Lett., 174, 553, (1990).

15. R.A. Mathles, A.R. Oseroff and L. Seryer, Proc. Nacl. Acad, Sci. USA, 73. 1. (1976).

16. T.N. Bulcan, M.J. Smyth, H.A. Crlssman, G.C. Salzman, C.C. Stewart and J.C. Martin, Appl. Opts., 26, 5311, (1987). 